\title{
ANALISIS INFORMASI EKONOMI DAN PENGGUNAAN TEKNOLOGI INFORMASI PADA INDUSTRI KREATIF DI JAWA, BALI DAN NUSRA
}

\section{Analysis of Economic Information and Information Technology on Creative Industries in Java, Bali, and Nusra}

\author{
I Made Endra Kartika Yudha*, Ida Bagus Putu Purbadharmaja \\ Fakultas Ekonomi dan Bisnis, Universitas Udayana \\ Jalan Raya Kampus Unud Jimbaran, Kabupaten Badung, Provinsi Bali 80361 \\ ${ }^{*}$ Alamat korespondensi : kartikayudha@unud.ac.id
}

(Tanggal Submission: 6 Agustus 2020, Tanggal Accepted: 2 September 2020)

\begin{abstract}
ABSTRAK
Informasi dan cara mengakses informasi merupakan hal peting dalam menentukan keputusan ekonomi. Kepemilikan informasi keuangan seperti laporan keuangan dalam sebuah perusahaan akan memberikan pengaruh terhadap pembuatan keputusan dan kemampuan perusahaan dalam mendapatkan modal usaha. Semakin baik kualitas informasi keuangan dan ekonomi dari sebuah perusahaan maka dipastikan perkembangan perusahaan tersebut akan semakin baik. Apabila informasi keuangan dan ekonomi tidak lengkap maka akan terjadi masalah yang disebut asymetric information. Informasi yang tidak sempurna akan menyebabkan kesulitan bagi pemerintah untuk menentukan arah kebijakan khususnya dalam membuat kebijakan untuk mendukung perkembangan industri kreatif di Indonesia. Industri kreatif harus dikelola secara baik dan memiliki manajemen keuangan yang lengkap. Apabila perusahaan dan pelaku dalam industri kreatif tidak memiliki informasi yang sempurna maka tentu akan menyulitkan investor untuk menanamkan modalnya. Selain itu penggunaan teknologi informasi seperti internet akan menentukan kualitas informasi bagi pelaku dan perusahaan dalam industri kreatif dan konsumen barang hasil produksi dari industri kreatif. Tujuan penelitian ini adalah untuk mengetahui karakteristik informasi laporan keuangan dan penggunaan teknologi informasi berupa internet dari setiap provinsi di Jawa, Bali, dan Nusa Tenggara. Data yang digunakan adalah data time series yang berasal dari Badan Ekonomi Kreatif Indonesia Tahun 2016. Data tersebut antara lain adalah data mengenai kepemilikan laporan keuangan dan data penggunaan internet oleh pelaku industri kreatif di setiap Provinsi Jawa, Bali, dan Nusa Tenggara. Hasil penelitian ini menunjukkan bahwa DKI Jakarta, Jawa Barat, dan Daerah Istimewa Jogjakarta memiliki karakteristik yang mirip dengan memiliki kualitas penggunaan internet yang baik dan kepemilikan laporan keuangan yang baik dibandingkan daerah lain, sehingga industri kreatif di daerah ini memiliki kinerja yang baik dalam mengakses pasar dan memiliki manajemen keuangan yang baik serta minim masalah adverse selection dan moral hazard..
\end{abstract}

Kata Kunci: Industri Kreatif, Asymetic Information, Laporan Keuangan, Internet 


\section{PENDAHULUAN}

Informasi adalah representasi dari pengetahuan, informasi juga merupakan data di dalam lingkungan yang diperoleh dari jarak sebuah rangsangan lingkungan dan fenomena, selain itu informasi juga bagian dari proses komunikasi yang berisi mengenai huruf dan data, informasi juga merupakan sumber atau komoditas (Madden, 2000). Informasi digunakan dalam setiap lini kehidupan sebagai alat untuk membuat keputuan yang tepat. Kebutuhan akan informasi sangat tinggi untuk menentukan keputusan - keputusan yang menghasilkan hasil yang efesien dan efektif. Informasi yang tidak sempurna akan menghasilkan kesalahan dalam pembuatan kebijakan atau kesalahan dalam menentukan pilihan sehingga menyebabkan kerugian yang dapat dialami baik itu pemerintah, perusahaan, dan konsumen. Informasi lengkap dan sempurna yang hanya dimiliki oleh satu pihak dan pihak lain tidak memiliki informasi disebut sebagai asymetric information. Asymetric information terjadi saat satu pihak terlibat pada proses transaksi menerima informasi yang lebih dapat dipercaya atau mendapatkan informasi yang lebih dibandingkan dengan pihak lain (Nurcholisah, 2016). Asymetric information yang menyebabkan kesalahan menentukan pilihan disebut sebagai adverse selection. Asymetric information juga menyebabkan terjadinya moral hazard, ini berarti salah satu pihak misalnya principle tidak dapat mengawasi tindakan pihak lain misalnya agent, sehingga akan terjadi kerugian pada pihak principle (Furboton and Ricther, 1998).

Informasi penting dalam perekonomian dan kegiatan usaha serta bisnis adalah laporan keuangan. Laporan keuangan merupakan laporan yang menggambarkan kondisi keuangan sebuah lembaga baik lembaga yang bersifat profit dan nonprofit. Fungsi utama dari laporan keuangan untuk menyediakan informasi mengenai keadaan keuangan, kinerja keuangan, dan dari bisnis yang akan membantu pengguna laporan untuk membuat keputusan (Salehi et al, 2014). Laporan keuangan dalam kegiatan usaha dan bisnis juga digunakan oleh bank dan investor untuk memberikan pinjaman untuk modal usaha, dan sebagai acuan bagi investor untuk menginvestasikan uang atau modalnya di sebuah usaha atau bisnis. Aktifitas publikasi informasi dari petugas investor relations (IR) dapat menurunkan masalah adverse selection yang berasal dari informasi yang tidak sempurna antara penjual dan pembeli di dalam pasar saham (Rodrigues and Galdi, 2017). Ini menunjukkan bahwa informasi keuangan menjadi sangat penting untuk menentukan keputusan. Kepemilikan informasi keuangan menjadi sangat penting saat ini, tanpa ada informasi keuangan dalam bentuk laporan maka tentu akan berpengaruh terhadap perkembangan usaha dan bisnis. Semakin besar sebuah usaha dan bisnis, maka kepemilikan laporan keuangan adalah wajib. Namun masih banyak juga usaha dan bisnis di dalam industri yang belum memiliki laporan keuangan. Ini berdampak kepada perkembangan industri tersebut. Semakin lengkap dan sempurna sebuah laporan keuangan, maka ini akan semakin baik bagi lembaga seperti bank dan non serta para investor yang akan memberikan dananya untuk dikelola oleh sebuah usaha dan bisnis. Asymetric information dalam perbankan dapat menyebabkan terjadinya adverse selection. Pada penelitian yang dilakukan oleh Crawford et al (2018), ditemukan bukti bahwa peningkatan masalah adverse selection akan menyebabkan peningkatan bunga dan standar serta menurunkan penawaran kredit. Penurunan penawaran kredit dari bank tentu akan memberikan dampak buruk terhadap perekonomian khsusunya pada sebuah industri. Informasi keuanga yang tidak lengkap dan tidak sempurna akan menyebabkan pihak bank atau investor akan kesulitan menentukan kebutuhan modal dan dana yang dibutukan untuk membuat sebuah usaha dan bisnis dapat tumbuh dengan baik. Informasi keuangan yang baik akan memberikan gambaran kepada pihak bank atau investor mengenai keberlangsungan bisnis atau sebuah usaha di dalam industri di masa yang akan datang. Sehingga hal ini menjadi sangat penting dan 
urgent untuk mengembangkan sebuah industri khususnya seperti industri kreatif.

Perkembangan penyebaran informasi telah semakin cepat dibandingkan beberapa dekade yang lalu. Informasi dapat tersebar dengan sangat cepat melalui teknologi informasi berupa internet. Teknologi informasi berupa internet telah menjadi sarana untuk memberikan dan mengakses informasi yang terkait dengan berbagai aspek kehidupan. Terdapat hubungan yang jelas antara kematangan ekosistem internt dan peningkatan standar hidup, bahwa kematangan internet pengalaman dari negara maju selama 15 tahun terakhir memiliki hubungan yang sangat kuat dengan peningkatan PDB dengan rata-rata $\$ 500$ sepanjang periode ini, bila dibandingkan dengan masa revolusi industri, perlu 50 tahun untuk mencapai hasil yang sama di masa sama dengan pencapaian yang diakibatkan oleh internet (Maynika dan Roxburg, 2011). Penggunaan internet telah memberikan dampak positif terutama pertumbuhan bisnis dan berbagai jenis usaha. Menurut Apăvăloaie (2004) bahwa internet telah merubah berbagai aspek kehidupan, namun lingkungan bisnis yang paling dipengaruhi dari perubahan dan perubahan yang signifikan, dimana e-busines menjadi area didalam kekuatan dari teknologi informasi tradisional yang terintergrasi dengan internet dan juga bekerja dengan visi bisnis yang baru.

Hal ini menyebablan internet sudah menjadi kebutuhan primer dan tentu menjadi faktor penting dalam pengembangan usaha kecil dan menengah dalam industri termasuk dalam industri kreatif. Internet dapat menyebabkan small and medium enterprises (SMEs) menghasilkan keuntungan dari internet dengan perusahaan memotong biaya dan meningkatkan keuntungan dari peningkatan dalam komunikasi dan mengakses informasi serta serta pemasaran (Guerriero, 2015). Internet dapat membuat SMEs merasakan dunia tanpa batas, dimana SMEs dapat berkompetisi dengan perusahaan multinasional dengan mengakses pasar yang berada di luar jangkuan (Dean et al, 2012). Perkembangan dalam penggunaan internet tidak berarti seluruh pelaku dalam industri dapat menggunakannya dengan baik dan maksimal, namun disisi lain masih banyak juga pelaku industri khususnya dalam industri kreatif tidak mempunyai kemampuan untuk mengakses dan menggunakan internet dengan baik. Untuk itu perlu diketahui menganai karakteristik industri kreatif di Jawa, Bali dan Nusra berdasarkan kepemilikan laporan keuangan dan penggunaan internet. Sehingga diketahui bahwa daerah mana yang memiliki kondisi karakteristik dengan kepemilikan laporan keuangan paling sedikit dan penggunaan internet terendah. Sehingga dapat dibuat kebijakan untuk meningkatkan kualitas tersebut, dan dapat diketahui juga daerah mana yang memiliki kinerja tinggi dan sudah memiliki manajemen keuangan yang rapi dan baik terukur dari kepemilikan laporan keuangan.

\section{METODE PENELITIAN}

Pada penelitian ini menggunakan data rasio penggunaan internet dan kepemilikan laporan keuangan terhadap total pelaku industri di setiap provinsi di Jawa, Bali dan Nusra pada tahun 2016, data bersumber dari Badan Ekonomi Kreatif Indonesia. Pada penelitian untuk menjelaskan karakteristik dari masing-masing daerah maka digunakan alat analisis multidimensional scaling (MDS). multidimensional scaling (MDS) merupakan model yang berhubungan dengan variasi dari model geometri yang mendefinisikan dari hubungan alami dari representasi spasial dan teknik yang berbeda untuk mencocokan beberapa model dari data, pada teknik MDS objek yang mirip akan didekatkan pada peta multidimensi ruang yang sama, semakin dekat objek tersebut dengan objek lain pada satu peta dimensi maka semakin mirp antara satu objek dengan objek lain (Weinberg, 1991). Ini berarti model ini berusa untuk mencari atau mengkelompokkan objek dengan karakteristik yang sama dalam satu ruang multidimensi. Model MDS yang baik adalah model yang memiliki nilai STRESS dibawah 2,5. Apabila nilai STRESS dibawah 2,5 maka model tersebut menunjukkan hubungan monoton yang terbentuk antara ketidaksamaan dengan jarak 
antara pasangan objek menjadi ukuran baru semakin baik dan kriteria peta persepsi yang terbentuk berarti sempurna, sehingga model layak digunakan (Putri et al, 2018). Alat analisis ini akan membagi setiap karakteristiknya dengan 4 kuardaran. Kuardran pertama (K.I) adalah daerah yang rasio kepemilikan dan rasio penggunaan internetnya sangat rendah dan kepemilikan laporan keuangan yang rendah. Kuardaran kedua (K.II) adalah daerah yang memiliki rasio kepemilikan laporan keuangan yang tinggi namun rasio penggunaan internetnya cukup rendah. Kuardran ketiga (K.III) adalah daerah yang memiliki penggunaan rasio internet yang tinggi namun memiliki rasio kepemilikan laporan keuangan yang rendah. Kuardran empat (K.IV) adalah daerah yang memiliki kepemilikan rasio keuangan yang tinggi dan penggunaan internet yang tinggi pula. Rasio keempat merupakan rasio yang utama dalam penelitian ini.

\section{HASIL DAN PEMBAHASAN}

Kepemilikan laporan keuangan adalah gambaran kualitas mengenai kepemilikan informasi pada industri kreatif di Jawa, Bali, dan Nusra. Penggunaan internet adalah gambaran kemampuan industri dalam mengakses internet untuk mendapatkan informasi dan memberikan informasi kepada pembeli dan stakeholder yang berkepentingan. Kepemilikan laporan keuangan dan pengguaan internet menjadi dua indikator sebagai karakteristik industri kreatif di Jawa, Bali dan Nusra. Untuk daerah NTT dan Jatim merupakan daerah dengan karakteristik dimana daerah ini memiliki kemiripan yang samaa dengan kecenderungan kepemilikan laporan keuangan yang relatif rendah dan penggunaan internet yang rendah. NTT dan Jatim termasuk daerah yang masuk dalam kuadran satu (K.I). Pada kuardran satu ini berarti industri pada kuardran tersebut memiliki resiko adverse selection dan moral hazard dan kinerja yang rendah untuk masuk ke dalam pasar baru karena jumlah penggunaan internet paling sedikit dibandingkan daerah lain. Untuk Jawa Tengah, Banten, dan NTB merupakan provinsi yang memiliki karateristik yang sama berada di dalam kuardran II (K.II). Banten merupakan daerah yang memiliki laporan keuangan yang paling tinggi dibandingkan seluruh provinsi di Jawa, Bali, dan Nusra. Ini berarti Banten memiliki resiko terjadinya moral hazard dan adverse selection yang terendah dibandingkan daerah lain, namun memiliki kelemahan berupa kekurangan penggunaan internet pada industri kreatifnya sehingga memiliki kekurangan kemampuan untuk mengakses pasar yang lebih luas dan meningkatkan ketungan. Berikut merupakan peta karakteristik industri kreatif pada masing-masing daerah.

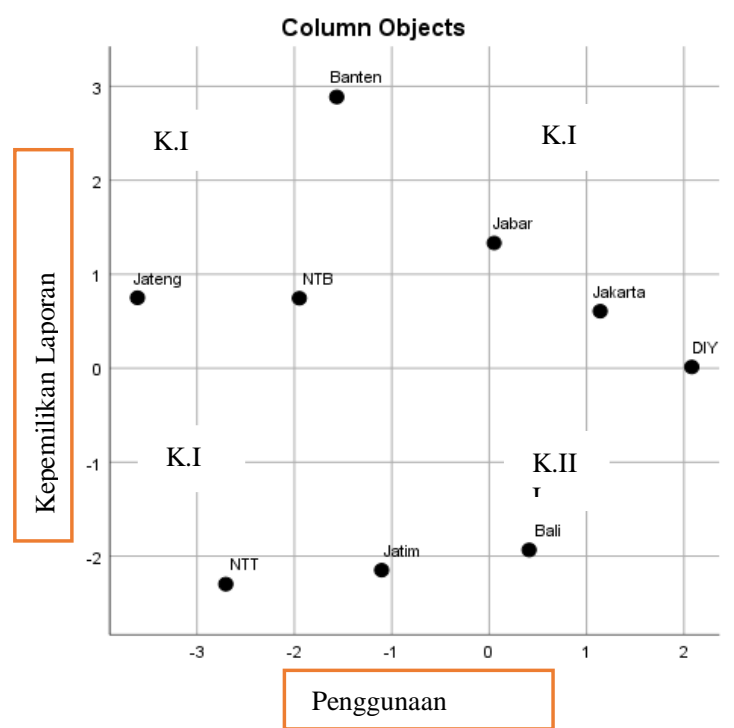

Gambar 1. Karakteristik Industri Kreatif pada Masing-masing Provinsi di Jawa, Bali, dan Nusra.

Bali merupakan wilayah yang masuk ke dalam kuardran 3 . Pada kuardran ketiga (K.III), Provinsi Bali cenderung memiliki industri yang menggunakan internet lebih banyak dibandingkan Provinsi pada kuardran 1 dan 2. Namun Provinsi Bali memiliki karakeristik industri kreatif yang memiliki penggunaan internet yang tinggi namun disisi lain, jumlah laporan keuangan yang lebih sedikit dibandingkan provinsi di kuardran 2. Ini berarti pada Industri kreatif di Provinsi bali terdapat kemungkinan terjadinya masalah adverse selection dan moral hazard, dibandingkan provinsi lain di kuardran 2 dan 4. Pada industri kreati di Provinsi Bali memiliki kelebihan berupa kemampuan untuk mendapatkan 
pasar yang lebih besar dan luas serta mampu mengurangi biaya dan meningkatkan keuntungan seperti temuan Guerriero (2015) dan Dean et al (2012) pada kasus SMEs. Kelemahanya dari industri kreatif di Provinsi Bali adalah kurangnya informasi keuangan sehingga hal ini menyebabkan permasalahan kepercayaan terhadap industri kreatif di Provinsi Bali khususnya bagi investor dan bank. Semakin baik sebuah usaha memiliki laporan keuangan, maka hal ini dapat meningkatkan kepercayaan bagi investor atau pihak bank. Tentu dengan laporan keuangan yang baik akan menyebabkan akan memudahkan pihak terkait dalam mengambil keputusan.

Provinsi Jawa Barat, Daerah Istimewa Jogjakarta (DIY), dan Jakarta merupakan daerah yang masuk dalam kuardran IV. Pada kuardaran IV merupakan kuardran yang dengan karakteristik yaitu memiliki kencenderungan penggunaan internet yang tinggi dan jumlah kepemilikan laporan keuangan yang lebih tinggi dibandingkan kuardran I, II, III. Pada kuardran ini, industri sudah tergolong lebih maju dan memiliki manajemen keuangan yang baik. Industri kreatif pada ketiga wilayah ini memiliki manajemen keuangan yang baik dan memiliki kualitas informasi keuangan yang tinggi dan penggunaan internet yang digunakan untuk mendapatkan informasi dan menyebarkan informasi. Pada wilayah ini, dapat dianggap yang sudah cukup maju dalam pengelolaan informasi dan keuangan. Pada wilayah ini, industri dapat dikatakan memiliki karakteristik informasi keuangan dan penggunaan internet yang baik sehingga akan mengurangi masalah advrese selection dan moral hazard. Pada wilayah ini berarti pihak bank dan investor dapat mendapatkan informasi yang baik sehingga menurunkan resiko dari masalah asymetric information. Berarti pada wilayah ini merupakan wilayah dengan kondisi industri yang maju, dimana industri kreatif dapat mengakses pasar yang lebih besar serta melakukan efesiensi biaya dan meningkatkan keutungan dan secara bersama sama mampu mengurangi masalah advrese selection dan moral hazard. Pada kurdaran empat ini industri memiliki informasi keuangan yang lengkap dan mampu mendapatkan pembiayaan dari bank atau investor secara mandiri dan profesional.

Provinsi yang masih berada di Kuardran satu (I) merupakan dua provinsi yang memiliki penggunaan internet dan kepemilikan laporan keuangan yang rendah. Untuk Provinsi NTT dan Jawa Timur perlu ditingkatkan kualitas kepemilikan laporan keuangan dan penggunaan internet pada industri kreatif sehingga dapat memberikan dampak positif antara lain meningkatkan kepercayaan investor dan lembaga keuangan seperti bank atau lembaga keuangan kepada industri kreatif. Peningkatan kualitas dan jumlah laporan akan sangat berguna bagi pengambil kebijakan, investor, lembaga keuangan bank atau non-bank, atau pengguna laporan keuangan dalam peningkatan perkembangan industri kreatif.

Model MDS yang baik adalah model yang memiliki beberapa kriteria tertentu yang baik antara lain memiliki nilai STRESS yang sesuai kriteria. Berikut merupakan nilai stress pada pada masing-masing kriteria. Pada tabel 1 dibawai ini merupakan nilai STRESS dari dua kreiteria yang digunakan.

Tabel 1. Nilai STRESS Pada Kriteria yang Digunakan Pada Penelitian

\begin{tabular}{ll}
\hline Kriteria & STRESS \\
\hline \hline Kepemilikan Laporan Keuangan & 0.000 \\
Penggunaan Internet & 0.000 \\
\hline
\end{tabular}

Sumber: Data Diolah (2019)

Pada tabel 1 diatas diketahui bahwa nilai seluruh STRESS adalah 0.000 . Nilai ini berada lebih kecil dari 2,5. Ini berarti menunjukkan hubungan monoton yang terbentuk antara ketidaksamaan dengan jarak antara pasangan obyek menjadi ukuran baru semakin baik dan kriteria perta persepsi semakin terbentuk sempurna. Dengan kata lain model MDS sudah layak digunakan untuk mengestimasi dan menganalisa kondisi informasi keuangan dan penggeunaan teknologi informasi pada penelitian ini. Untuk lebih lanjut, maka perlu dilakukan penelitian lebih lanjut mengenai kualitas laporan keuangan seperti apa yang dibutuhkan 
untuk mendukung perkembangan industri kreatif dan kualitas penggunaan internet seperti apa yang harus digunakan untuk mendukung dan mendorong industri kreatifi di Pulau Jawa, Bali dan Nusa Tenggara.

\section{KESIMPULAN DAN SARAN}

Hasil penelitian ini menunjukkan bahwa DKI Jakarta, Jawa Barat, dan Daerah Istimewa Jogjakarta memiliki karakteristik yang mirip dengan memiliki kualitas penggunaan internet yang baik dan kepemilikan laporan keuangan yang baik dibandingkan daerah lain. Ini berarti pada daerah ini merupakan daerah yang memiliki industri kreatif yang berkinerja tinggi karena memiliki penggunaan internet yang tingggi dan memiliki laporan keuangan yang lebih banyak dibandingkan daerah lain dan telah memiliki manajemen keuangan yang lebih baik dan rapi dibandingkan daerah yang lain. Dapat disimpulkan bahwa industri kreatif di Provinsi DKI Jakarta, Jawa Barat, Daerah Istimewa Jogjakarta memiliki kemampuan manajerial keuangan yang baik dan mampu secara mandiri dalam mendapatkan modal dari bank dan investor karena memiliki resiko kecil terkati masalah adverse selection dan moral hazard dibandingkan provinsi lain, ini berarti tidak perlu banyak campur tangan pemerintah untuk meningkatkan modal dari industri kreatif. Selanjutnya untuk daerah seperti Provinsi Jawa Timur dan NTT yang memiliki penggunaan internet yang rendah dan kepemilikan laporan keuangan yang rendah dibandingkan daerah lain, maka diharapkan untuk meningkatkan kualitas kecakapan penggunaan teknologi internet agar dapat mengakses pasar yang lebih luas dan meningkatkan jumlah kepemilikan laporan keuangan agar mengurangi resiko adverse selection dan moral hazard sehingga lebih memudahkan untuk mendapatkan modal baik dari lembaga keuangan atau investor, dan tentu ini harus mendaparkan perhatian khusus dari pemerintah agar memiliki kemampuan manajemen keuangan yang baik digambarkan dengan kepemilikan laporan keuangan.

\section{DAFTAR PUSATAKA}

Apăvăloaie, E-I. 2014. The Impact Of The Internet on The Business Environment. Procedia Economics and Finance. 15: 951-958. :https://core.ac.uk/download/pdf/8279034 5.pdf.

Crawford, G. S., Pavanini, N., And Schivardi, F. 2018. Asymmetric Information and Imperfect Competition in Lending Markets. American Economic Review 2018, 108(7): 16591701:https://www.aeaweb.org/articles?id= 10.1257/aer.20150487

Dean, D., et al. 2012. The Internet Economy in the G20. Report The Boston Consulting Group. :https://www.bcg.com/publications/2012/t echnology-digital-technology-planninginternet-economy-g20-4-2-trillionopportunity.aspx

Furboton, E. G., and Richter, Rudolf. 1998. Institutions and Economics Theory: The Contribution of The New Institional Economics. The University of Michigan Press.

Guerriero, M. 2015. The Impact of Internet Connectivity on Economic Development in Sub-Sahara Africa. EPS-PEAK Our Expertise Knowledge.

1(27).:https://assets.publishing.service.gov. uk/media/57a0899b40f0b652dd0002f4/Th e-impact-of-internet-connectivity-oneconomic-development-in-Sub-SaharanAfrica.pdf.

Madden, A. D. 2000. A Definition of Information. Aslib Proceedings. 52. 343-349. :https://www.researchgate.net/publication /241708484_A_definition_of_information.

Maynika, J., and Roxburgh, C. 2011. The Great Tranformer: The Impact of The Internet on Economics Growth and Properity. Mc Kinsey Global Institute. :https://www.mckinsey.com/industries/hig 
h-tech/our-insights/the-great-transformer. Diakses pada tanggal 17 September 2019.

Nurcholisah, K. 2016. The Effects Of Financial Reporting Quality On Information Asymmetry And Its Impacts On Investment Efficiency. Internasional Journal Of Economics, Commerce and Management. Vol 5: 838 - 850. :http://ijecm.co.uk/wpcontent/uploads/2016/05/4552.pdf.

Putri, DS., Wahyunsih, S., Goejantoro, R. 2018. Analisis Positioning dengan menggunakan Multidimensional Scaling Nonmetrik (Studi Kasus: Data Persepsi dan Perefensi Berdasarkan Jarak Merek Smartphone di Samarinda, Kalimantan Timur). Jurnal EKSPONENSIAL. 9(1): 85-94. : https://fmipa.unmul.ac.id/files/docs/[11]\% 20Devy\%20Sintya\%20Putri_Edit.pdf.
Rodrigues, S. D. S., and Galdi, FC. 2017. Investor Relation and Information Asymmetry. Revista Contabilidade \& Finanças. 12 (74): 297-312. http://dx.doi.org/10.1590/1808057x201703630.

Salehi, Mahdi., Rostami, Vahab., and Hesari, Hamid. 2014. The Role of Information Asymetry in Financing Methods. Spring. Managing Gobal Transition. 12(1): 43-54. :http://www.fmkp.si/zalozba/ISSN/1581-6311/12_043054.pdf.

Weinberg, SL. 1991. Methods, Plainly Speaking: An Introduction to Multidimensional Scaling. Measurment And Evaluation in Conseling and Developement. 24 (1) : 12-36. https://www.researchgate.net/publication /232428195_An_introduction_to_multidim ensional_scaling 